\title{
Professor Dr. D. A. de Jong-Stichting.
}

Verslag over de verrichtingen en den toestand over het jaar 1933.

In het verslagjaar werd de bewerking der eerste van de Stichting uitgaande publicatie ter hand genomen en vrijwel beëindigd. ${ }^{\text {) }}$

Het aantal vereenigingen en personen, dat de Stichting steunde door het verleenen eener vaste bijdrage, bleef gelijk. Ook van de Maatsch.ij voor Diergeneeskunde werd de gewone bijdrage, 1.- gld. per lid, ontvangen. Op de waarde der effecten werd per 31 December 1933 een koersverlies geleden groot $f$ 70.19. Het kapitaal der Stichting bedroeg op dien datum $f$ 15382. 48, waarbij dient te worden aangemerkt, dat een gedeelte der kosten van de publicatie komt ten laste van de rekening over 1934.

Door de herbenoeming van Dr. Van Nederveen als vertegenwoordigend beheerder vanwege de Mij. voor Diergeneeskunde, die als zoodanig met ingang van 1934 aan de beurt van aftreding was, kwam in het college van beheerders geen verandering. Het bestaat ook voor het loopende jaar uit de Heeren: Dr. J. J. F. Dhont, voorzitter, Prof. Dr. W. C. de Graaff, Prof. Dr. R. de Josselin de Jong, Prof. C. F. van Oyen en Dr. H. J. van Nederveen, secretaris-penningmeester (adres: Neuhuyskade 61, postrekening 105194, 's-Gravenhage).

De secretaris-penningmeester,

H. J. VAN NEDERVEEN.

's-Gravenhage, Mei 1934.

1) Inmiddels Februari 1934 verschenen. 